Sustinere

Journal of Environment and Sustainability

Volume 2 Issue 3 (2018) 128-143

Print ISSN: 2549-1245 Online ISSN: 2549-1253

Website: https://sustinerejes.comE-mail:sustinere.jes@iain-surakarta.ac.id

\title{
RESEARCH PAPER \\ The negative impact of illegal gold mining on the environmental sector in Batang Asai, Jambi
}

\author{
Try Susanti ${ }^{1}$, Wiji Utami ${ }^{1}$,*, Hidayat ${ }^{1}$, Desia Amimi ${ }^{2}$ \\ ${ }^{1}$ Laboratorium Terpadu Universitas Islam Negeri Sulthan Thaha Saifuddin, Jambi, Indonesia \\ 2 Dept. of Biology Education, Universitas Islam Negeri Sulthan Thaha Saifuddin, Jambi, Indonesia \\ Article history: \\ Received 13 July 2018 | Accepted 13 December 2018 | Available online 31 December 2018
}

\begin{abstract}
The negative impact of Illegal Gold Mining / IGM on the environmental sector in Batang Asai District, Sarolangun Regency, Jambi was investigated through a descriptive qualitative method. The purpose of this study was to determine the negative impact of IGM activities to several ecosystems, the effect of IGM on community activities, and some efforts to reduce IGM. The instruments of data collection included observation, interviews, and documentation. Data were analysed through data reduction, data presentation, and conclusion withdrawal. The results showed that IGM activity had a negative impact on the environment namely noise pollution, dust, degradation on the quality of Batang Asai River, forest conversion, river siltation, the emergence of large holes, overburden, soil abrasion, the disappearance of Meranti plants (Shorea sp.) and Damar (Agathis Damara). Besides that, other impacts were the declining population of Semah Fish (Tor sp.) which had become the special characteristic of fish in the area. Some efforts were made by the government to overcome and foster IGM activities, e.g. by providing counselling and sanctions in a judicial and non-judicial manner that was carried out continuously.
\end{abstract}

Keywords: gold mining without permission; river siltation; environment; Semah fish (Tor sp.)

\section{Introduction}

In Indonesia, Illegal Gold Mining / IGM activities are considered as one of the Unlicensed Mining (PETI) phenomena. The IGM was carried out by small-scale workers without permits from the local government (Dutu, 2016). Such mining process has attracted the attention of the scientific community to conduct a study about the detrimental effect it potentially brings to the environment. IGM has a negative impact on the environment which results in the disruption of the ecosystem balance. Not only does the environment get the influence of these activities, but the workers who carry out IGM activities will get a direct and indirect impact. The negative impacts of the IGM activity include the production of heavy metal mercury ( $\mathrm{Hg}$ ) waste (Nakazawa et al., 2016), the emergence of various diseases (Zolnikov, 2012), the emission of arsenic waste (As) (Shepherd et al., 2018), and river siltation (Veiga et al., 2014).

\footnotetext{
* Corresponding author. E-mail: wijiutami27 @gmail.com

DOI 10.22515/sustinere.jes.v2i3.43
} 
The number of workers involved in IGM was more than fifty million spreading across seventy (70) developing countries in Africa, Asia and South America (Telmer \& Veiga, 2008; Zolnikov, 2012). IGM workers generally do not only consist of adult men, but women and children are also generally involved in these activities. This condition is promoted by the lack of knowledge about the gold mining process in accordance with the Standard Operating Procedure (SOP) (Zolnikov, 2012). Insufficient knowledge and amalgamation techniques carried out by IGM workers can cause leaks of heavy metal mercury (Hg). Heavy metal mercury ( $\mathrm{Hg}$ ) waste is a serious risk that can easily be emitted around the gold mining area. Small amounts of heavy metal exposure to mercury $(\mathrm{Hg})$ can cause a very dangerous disease in humans.

The World Health Organization (WHO) (Nakazawa et al., 2016) reported that the concentration of heavy metal mercury that can be tolerated in humans is $200 \mathrm{ng}-3$ per year. The uniqueness of chemical properties of heavy metal mercury $(\mathrm{Hg})$ is that it will not be detected in any surrounding areas except on emissions sites. The emission site is the location of IGM practice where heavy metal mercury $(\mathrm{Hg})$ is used in the gold refining process. IGM activities contribute one-third of heavy metal mercury $(\mathrm{Hg})$ emissions to the world as pollutants (Kumar et al., 2018). The pollutant will decrease the environmental quality and as the consequence, it can cause various health problems.

Health problems that arise will not only attack humans but can also harm other living things in the ecosystem. In Peru, a study was conducted on monomethylmercury contamination (mmHg) in bats in the mining area. It was found that there was an increase in mmHg levels in the bat feathers of the last 100 years. The highest concentration of mmHg was found in adult and adolescent female bats. We all know that bats have a very important ecological function e.g. in the process of pollination, grain dispersal, and insect control (Kumar et al., 2018).

Heavy metal deposits of mercury (Hg) at normal temperatures will be easy to flow to bodies of rivers, lakes, and oceans. If this happens, metals will accumulate in aquatic organisms such as fish, squid, shrimp and others (Limbong et al., 2003). It is generally known that some species of aquatic organisms are consumed by humans as sources of protein. Gold mining activities around Kao Bay, North Halmahera Regency emits heavy metal content of mercury (Hg) in fish species of jackfruit seeds (Upenus sulphureus), which is in fish liver around 0.45-0.51 ppm and in fish meat 0.03-0, 04 ppm, causing it harmful to consume (Simbolon et al., 2010).

IGM phenomenon occurs in many regions in Indonesia including Pekan Gedang Village, Batang Asai District, Sarolangun Regency, located in Jambi Province. In this area, IGM practice is an economic source for the surrounding community. Based on the interviews conducted by researchers with one of the Tetuo villagers, the Batang Asai River had been full of waste so that while in the past, the community could use the river for their main activities such as bathing, washing and taking drinking water, now it is no longer possible due to the decrease in river water quality. The decline in the quality of the Batang Asai River water appeared cloudy due to IGM activities carried out in the area. This is supported by preliminary observation data conducted by researchers (Supangat, 2013; Nurdawati et al., 2006).

The researcher conducted an initial observation on January 8, 2018, in Pekan Gedang Village. The obtained data reported that there were many gold mining activities along the river. Mining was not only conducted in rivers but also in riverbank forests, resulting in forest 
destruction such as the loss of some vegetation. The loss of forest vegetation in the watershed increased the rate of abrasion. Abrasion that continuously happened in the rainy season could lose the topsoil and lead to the siltation on rivers. Based on the explanation above, studies on the impact of unlicensed gold development on the degradation of river and forest ecosystems in the Sarolangun district, Jambi needed to be done to provide more comprehensive and balanced information. Comprehensive knowledge of the natural resource will make people smarter and wiser in natural exploration (Ramires, 2007).

\section{Literature review}

Illegal Gold Mining (IGM) is a problem that occurs a lot in some regions that contain gold. IGM activities greatly affected various sectors of political, socio-environmental, educational and economic life (Avcl, 2015). The impact became a pro-contra among the community, especially in the economic sector. Many people have lifted their lives by conducting IGM activities such as being able to enrol children in higher education. This is a positive impact given by IGM activities, but the damage caused is very significant and influential in the future. In this case, there should be a role from the government in addressing and resolving problems caused by IGM activities.

Previous research explained that mercury $(\mathrm{Hg})$ could enter the atmosphere and aquatic cycle due to natural and anthropogenic activities, for example, coal plant waste, gold, and waste combustion (Engstrom et al., 2014; Kumar et al., 2018). The observation about mercury levels in North America was carried out by Daniel et al., (2018) at four lakes, namely Arctic, Southeastern Alaska, Western Newfoundland, and Northern Minnesota. It indicated that there was an increase in the mercury emissions after entering the 16th century when the gold and silver industries began to develop (Engstrom et al., 2014). At the study of Ferring et al., (2016) was conducted, there were around 25 million people registered as gold mine workers in the world. IGM activities were carried out by unprofessional miners so that accidents and poisoning due to mercury were often overlooked (Steckling et al., 2017).

Environmental pollution is not only caused by metal mercury due to the purification process of gold but also by cyanide compounds. Cyanide compounds are used as post-treatment after the purification using mercury metal. Cyanide compounds will be exposed freely if not controlled and treated. This often occurred in small and illegal gold mines (Veiga et al., 2014). Exposure to cyanide compounds has been studied by Razanamahandry et al., (2018) which explained that the spread of cyanide waste was influenced by the climate and soil type. In dry conditions, the spread of cyanide compounds is only affected by soil. Whereas, in humid conditions, the spread of cyanide is influenced by soil type and conductivity. In addition, environmental factors also influenced the distance between the cyanide zone and topographic elevation (Christine et al., 2018).

Pollutants emitted from gold mining have a huge negative impact on the environment and other sectors. Like Burkinso Faso (South Africa) is known as the biggest gold producer on the continent of Africa. The gold industry has developed since 1987 and increased massively in 2008 to become the source of life for 12 million people (a total of 17 million people). However, the private sector that cooperated with the government received huge profits, causing various violent conflicts between mine workers and local residents (Werthmann, 2017). Based on the explanation above, the research was decided to conduct at Batang Asai, Sarolangun since it 
became the centre of IGM activity to support the economy of the local community. It was the first research about IGM activities conducted on the Batang Asai River.

\section{Methodology}

\subsection{Research site}

The research was conducted for four months (February-May 2018), in Pekan Gedang Village, Batang Asai District, Sarolangun District, Jambi Province. This location was selected because, in this area, the local communities were also involved in mining activities. They were not only adult men but also many of them were women and children. Based on interviews and preliminary observations carried out by researchers, it was identified that there was degradation of environmental quality including ecosystems in forests and rivers.

\subsection{Data collection}

Data collection has been carried out through observation (Rettberg \& Ortiz-Riomalo, 2016) interviews, and documentation (Palacios-torres et al., 2017). Interviews were conducted to obtain deep information from the Village Head, Community Leaders, Indigenous Peoples, Regional Governments, Regional Police Head, and communities living around the river banks. Location and respondents were determined intentionally (purposive sampling) (Andri et al., 2011; Hoeber et al., 2017) considering the occurrence of IGM activities along the Batang Asai River. This study employed a descriptive qualitative research approach that revealed social situations by describing the reality precisely, in the form of words based on the techniques of collecting and analyzing relevant data which were obtained from natural situations. The data were then analyzed using techniques of data reduction, displays, and verification.

\subsection{Data resources}

Two different data obtained were the primary and secondary. The primary data in question included the objects, sites, and interviews which were collected by observation and interviews. Meanwhile, secondary data were obtained from magazines, newspapers, brochure, and nonresearcher parties.

The interviews to collect the primary data were conducted to the Village Heads, Custom Stakeholders, Community Leaders, Regional Governments, Head of Regional Police, and some selected communities. The source of the data about the atmosphere in this study was the environmental conditions around the mine. While the sources of documentation data were photos taken during the study conducted and other documentation archives. Observations were made by watching the activities of people in Pekan Gedang. From the observations, some information obtained included people's knowledge about the impact of PETI, the PETI business which involved investors who could rent and even buy excavators, the condition of primary forests that turned into mining land, damaged forests to be used as land for PETI, and decreased community activities on the river caused by the poor water quality due to the impact of PETI.

\section{Results and discussions}

Pekan Gedang village that has a tropical climate has a temperature of around $23-32^{\circ} \mathrm{C}$, humidity of 78\%, and rainfall of $260 \mathrm{~mm}$ year-1 with an area of 4,700 Ha (Village Head, 2017). The population in the area in 2017 was 1,271 who were members of 318 households. The communities were divided into two tribes namely Pengulu (West Sumatra) and Batin (Jawa- 
Mataram). In general, communities worked as a farmer, entrepreneur, civil servants (PNS), and honorary employees. In addition, the people of Pekan Gedang Village conducted Illegal Gold Mining (IGM) activities to meet economic needs.

IGM activities carried out in the area caused considerable damage to the ecosystem. As the consequence, the phenomenon of environmental damage caused by IGM attracted the attention of the scientific community to study it more extensively to prevent and reduce more severe damage. This problem was not only the responsibility of the Ministry of Energy and Mineral Resources (ESDM) but also that of all levels of society. The activities carried out in Pekan Gedang Village was a gold mining business conducted by individuals, groups or small companies, but did not get permission from government agencies (Spiegel, 2012). Information obtained from the Village Head indicated that the condition of Pekan Gedang Village was different from the situation before the mining conducted. In the past, the mining business was carried out using only simple equipment but when IGM activities were carried out, heavy excavators as ground diggers had been utilized.

\subsection{The impacts of IGM activities on the environmental sectors}

Based on observations made in the village, river ecosystems had been disrupted by the IGM activities coupled with the tendency of people throwing household trash in rivers which could increase the level of river pollution. River pollution is a serious disturbance causing alarming effects on various living things on earth including humans, animals and plants. The increase in the production activities will definitely increase the amount of waste and the intensity of pollution in the river. The data from interviews and observations conducted to investigate the negative impacts of IGM activities on the environment of Pekan Gedang Village are shown in Table 1.

Table 1. The negative impact of IGM activities on the environment of Pekan Gedang Village

\begin{tabular}{l} 
Negative impacts on the environment \\
\hline Sound and dust pollution \\
The decrease on water quality of the Batang Asai river \\
Forest conversion is the location of IGM activities \\
The Batang Asai River was silting and widening \\
The population of Semah Fish (Tor sp.) decreased \\
The occurrence of the hole due to IGM activities \\
Abrasion on the outskirts of the Batang Asai River and the land around the hole due \\
to IGM activities
\end{tabular}

Based on Table 1, it can be seen that this activity was very dangerous in the environmental sector. This is consistent with previous research conducted in Geita, Tanzania, which found that illegal mining activities could have a negative impact on the environmental sectors, which in this case included water pollution which contained cyanide (CN), dust, excavation, building collapse, rock destruction, and landslides. Within a year, 52 houses belonging to residents in Geita collapsed (Kitula, 2006). 


\subsubsection{Sound and dust pollution}

IGM activities produced noise pollution due to the use of heavy equipment i.e. excavators and dompeng machines in the process of extracting land containing gold. This pollution disturbed not only mining workers but also the surrounding community. Drilling, crushing and grinding the land produced noise and dust and affected miners who did not occupy Personal Protective Equipment (PPE) in accordance with the SOP. IGM activities lasted for 24 hours and could only stop during Friday afternoon, when there was a resident passing away, and after the occurrence of natural disasters. Exposure to existing noise and dust pollution could cause hearing loss and pneumonia. This was in accordance with the results presented by Zvarivadza and Nhleko (2017) stating that unlicensed gold mining activities could cause noise and dust pollution. Auger et al. (2018) stated that noise pollution provided a negative impact on human health in the form of preeclampsia, which in this case was high blood pressure that attacked pregnant women.

\subsubsection{The decrease of the water quality of Batang Asai River}

Mining workers generally did not understand the concept of 12 principles of green chemistry to preserve the environment. As a result of IGM activities, river water that used to be clear now tends to be impossible to meet the needs of the surrounding community. Declining river water quality was characterized by the high turbidity which can be seen in Figures 1 and 2 . People who used river water for the daily need will experience skin diseases (itching).

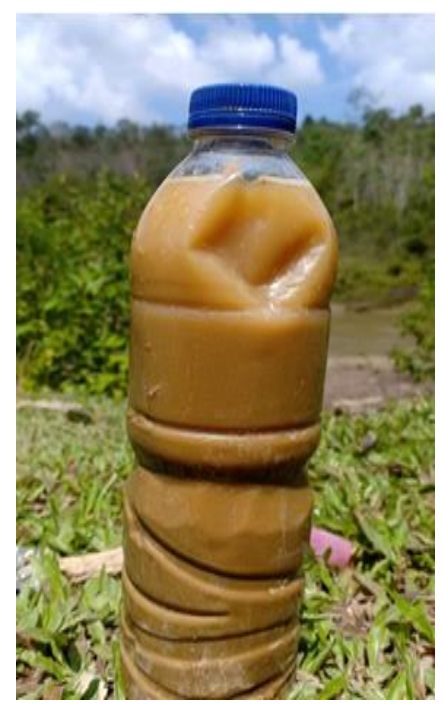

(a)

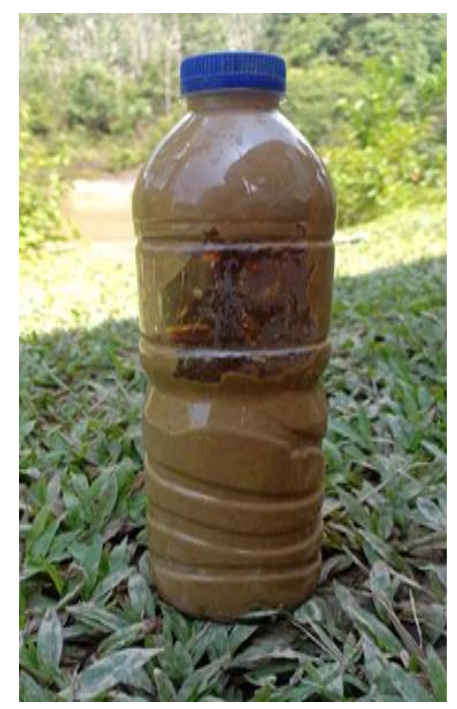

(b)

Gambar 1. The water quality in the Batang Asai River (a) River water samples, (b) River soil samples

Based on Figures 1 (a) and 1 (b), it can be seen that the colour of the water samples and the soil of the Batang Asai River were brown and very cloudy. This is extremely improper to be used to meet people's needs. The purification process that uses heavy metal mercury $(\mathrm{Hg})$ enters the river and pollutes the environment. Mercury has the potential to be absorbed and processed by anaerobic bacteria which are then transformed into methylmercury. These compounds have characteristics that can accumulate in living tissue (bioaccumulation) such as fish, shrimp and all river animals. This fish and shrimp will be consumed by the surrounding community and can 
cause dangerous diseases (Angel et al., 2013; Male, Reichelt et al., 2013; Veiga et al., 2014). Heavy metal mercury (Hg) which accumulates in the liver will cause hepatotoxicity (Hazelhoff \& Torres, 2018).

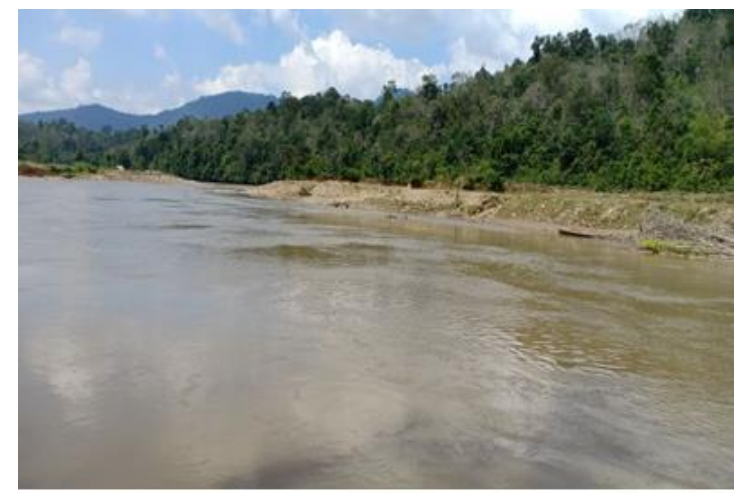

(a)

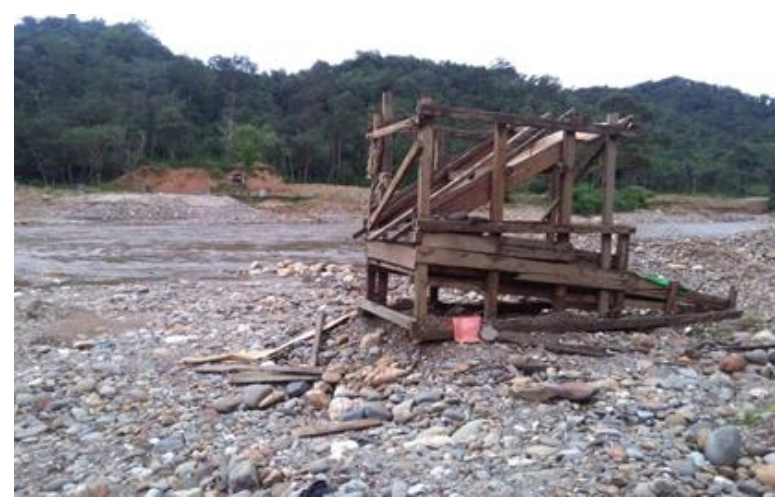

(b)

Figure 2. Conditions of the Batang Asai River (a) Water flowing in the Batang Asai River and (b) Equipment left by mining workers on the riverbank.

Heavy metal mercury ( $\mathrm{Hg}$ ) will continue to accumulate in the environment if the current method is not changed for refining. Several methods had been offered to reduce mercury emissions into the environment, namely retorts, mill leaching, and vat leaching. While chemical compounds that could be used to replace heavy metal mercury ( $\mathrm{Hg})$, were e.g. magnetism, direct smelting, water flow (sluices), and borax (Zolnikov \& Ortiz, 2018). In Figures 1 (b) and 2 (a), it can be seen that the condition of the river experiencing widening and equipment left by the miners once the area did not produce gold anymore. This could be very detrimental to the environment in terms of cleanliness and aesthetics. This would continue to occur because of the lack of knowledge of mine workers about the gold mining process in accordance with the rules.

\subsubsection{Forest conversion is the location of IGM activities}

IGM activities in Pekan Gedang Village lasted a long time, which were initially only carried out around settlements and community-owned agricultural land. The condition of IGM can be seen in Figure 4 and has now entered the forest area. Mine workers travel a considerable distance of 3-5 $\mathrm{km}$ to enter the forest by following the river using a simple canoe. Instead of being preserved, the trees in the forest were indeed continued to be cut down and the area was excavated to mine gold. If forest clearing continues to occur, this will cause disturbance to the forest ecosystem, included deforestation, disruption of wildlife populations and the loss of biodiversity in the forest. This can be seen in Figures 2, 3 and 4.

In Figure 3, it can be seen that the forest was suffered considerable damage since the excavation process did not only use a dompeng machine but also an excavator as shown in Figure 4. Excavation can be done in one day with an area of more than $5 \mathrm{~m}^{2}$. If the location is no more productive, it will be left without reclamation and reforestation. The typical vegetation of the area which had been reduced was the meranti tree (Shorea sp.) and resin (Agathis Damara). The excavation process would be then carried out in a new place. It is consistent with the study 
conducted by Owusu-Nimo et al. (2018) stating that gold mining activities in Ghana caused deforestation and the reclamation process needed a minimum of 10 months (Tudesque et al. 2012).

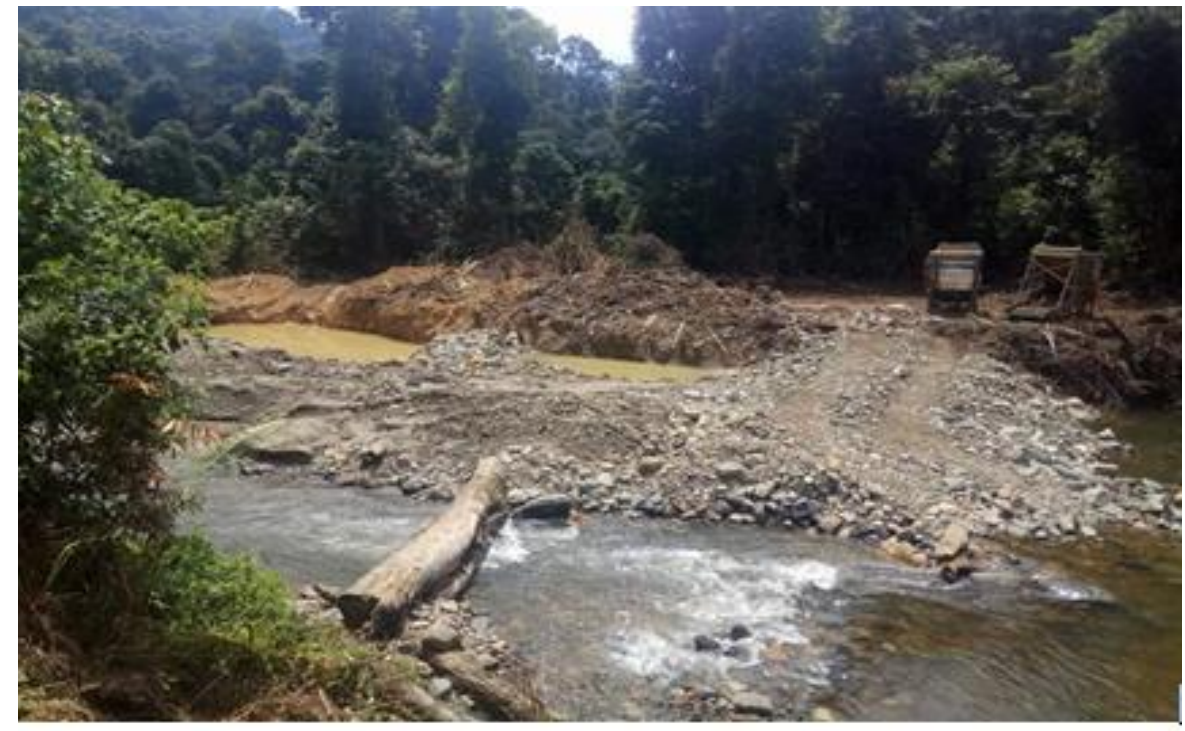

Figure 3. Forest clearance is the location of IGM activities

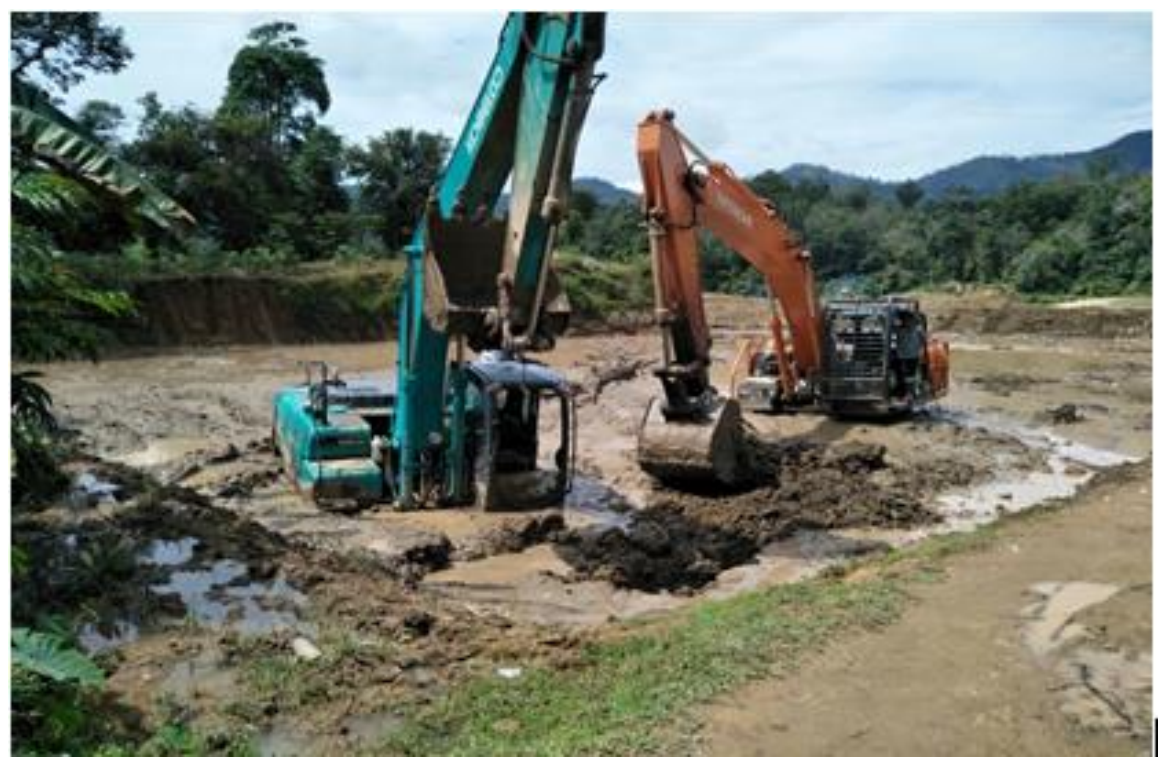

Figure 4. IGM activities on community farms (rice fields) 


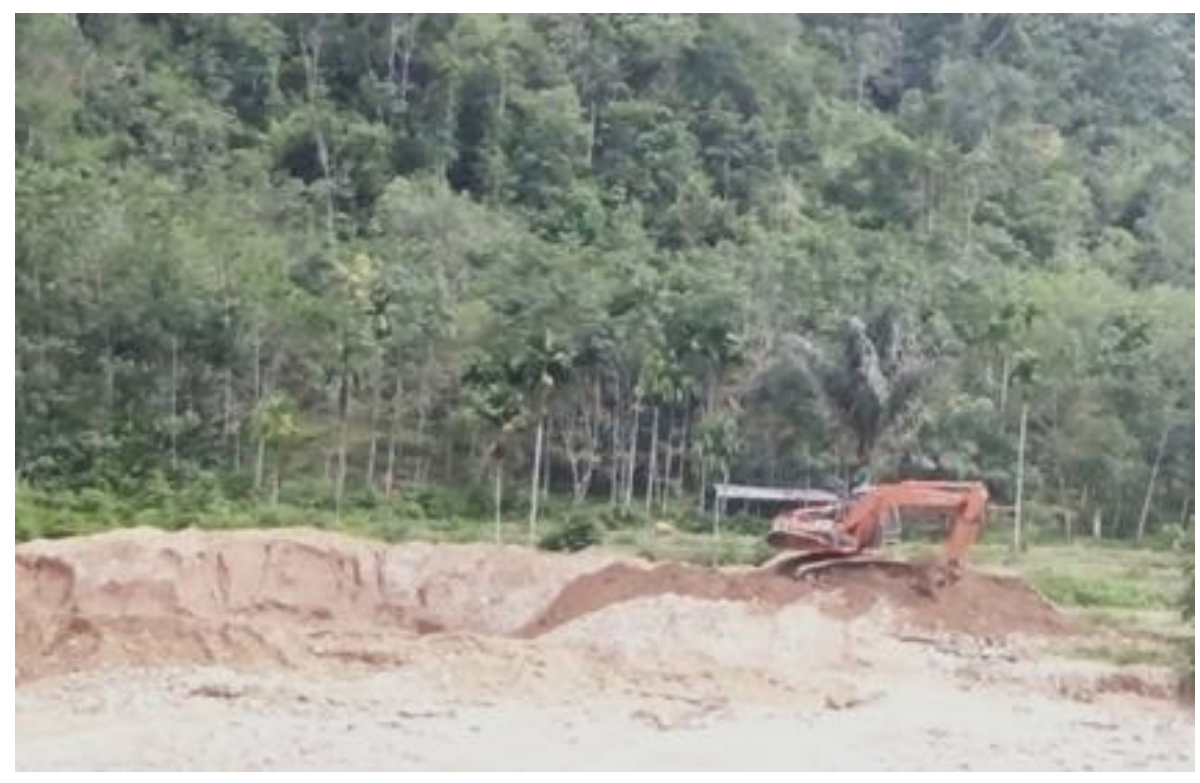

Gambar 5. The use of excavator in the excavation process.

\subsubsection{The silting and widening of the Batang Asai river}

Gold commodities and other types of stone have a very high selling value that can improve people's lives. Mining can be done after receiving permission from the government and involving well-trained workers so that they understand all restrictions and the required treatment after the mining process. A group of mining workers generally consist of 2-20 members who usually still have kinship relationships consisting of men, women and children (Zvarivadza \& Nhleko, 2017). IGM activities in Pekan Gedang Village have had a negative impact on the Batang Asai River e,g, the widening and silting of river bodies. It can be seen in Figures 6 and 7.

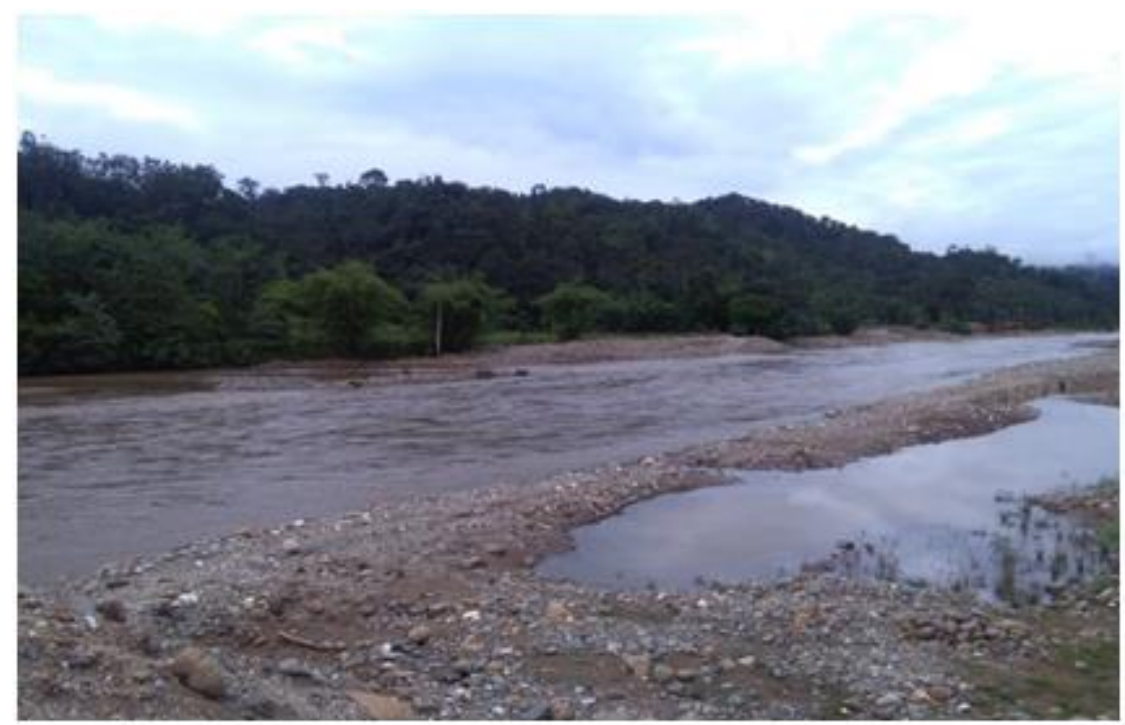

Figure 6. Silting of the Batang Asai River due to IGM activities 


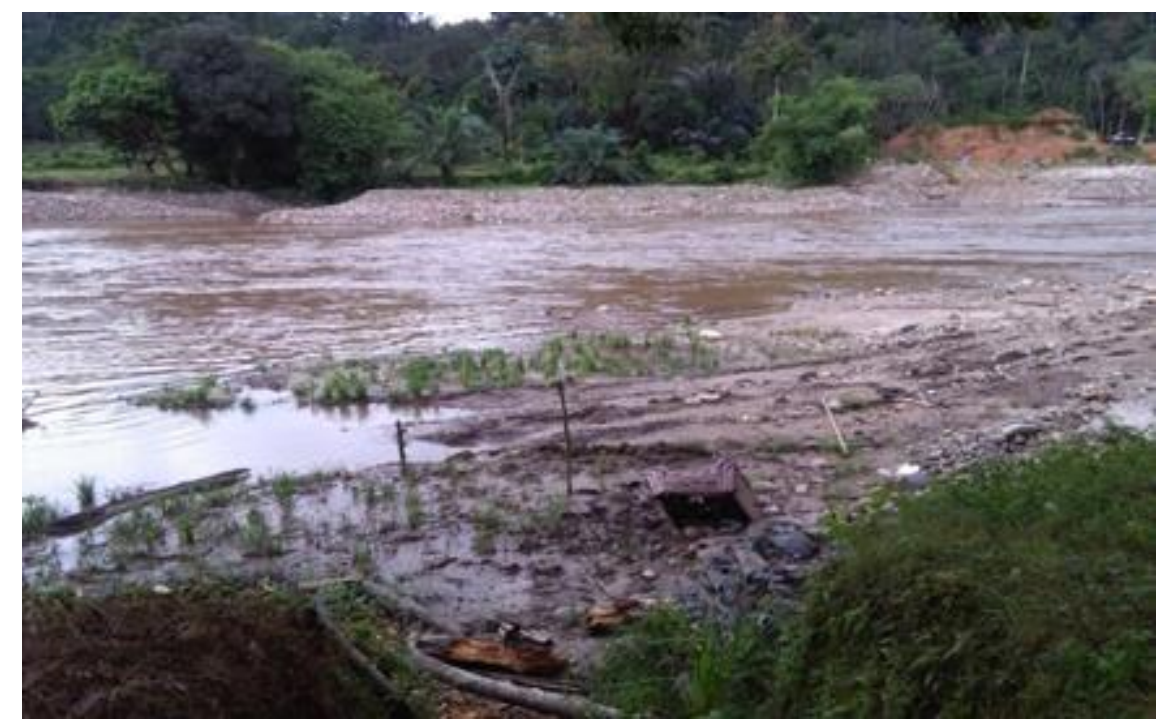

Figure 7. Widening of the Batang Asai River due to IGM activities.

Based on Figures 6 and 7, it can be explained that IGM activities that had evolved into the forest have also damaged the river. If this continues without any guidance and control, there will be a loss of river ecosystem due to silt deposition. The process of extracting and suctioning the soil will result in changes in soil structure on the riverbed and the area around the river. The soil will become softer and easily degraded. The structure of soil on the riverbed is no longer strong and it will slowly accumulate deposits. Accumulation of sediments for long periods of time will cause loss of river ecosystems and aquatic biota. Wildlife that lives depending on the river water will die and damage the food chain balance (Zvarivadza \& Nhleko, 2017).

\subsubsection{The decreased population of Semah Fish (Tor sp.)}

Pollutants caused by IGM activities could disrupt the environment. penThe siltation of the river that occurred in the Batang Asai River resulted in a decline in Semah fish population (Tor sp.). Semah (Tor sp.) is a typical fish in the Batang Asai sub-district. The river has no function due to IGM activities. Local people can no longer fulfil the need for animal protein from Semah Fish (Tor sp.). At present, if residents want to consume these fish, then they have to import from other regions at a high price. Such condition also happened in Tatelu, North Sulawesi that before mining conducted in the area, the agriculture and fisheries sector became a source of livelihood for local residents. However, the mining activities had deteriorated the forest biodiversity and declined the fish populations in the waters (Langston et al., 2015).

\subsubsection{Holes due to IGM activities}

Mine workers take that the land to extract the gold using dompeng machines and excavators that can cause large holes. This hole will cause soil degradation around the mining site. The locations of IGM activities that were not recovered by reclamation and reforestation will damage land mounds which makes the location difficult to be reused for other sectors such as agriculture as presented in Figures 8 and 9. 
It can be seen in Figures 8 and 9 that in the rainy season the hole can hold rainwater so that it resembles small lakes. The colour of the inundation water in the holes is brown, bluish green and red. The water cannot be used by residents because it contains pollutants. This condition can be a place for breeding vectors of disease, namely mosquitoes and water lice. Risks and accidents due to holes do not only threat the mine workers, but also the local people. The uneven impact of overburden (over soil) disturbed farmers who want to find grass as cattle feed. Reclamation and reforestation are needed to prevent larger disasters, namely landslides and floods (Kitula, 2006).

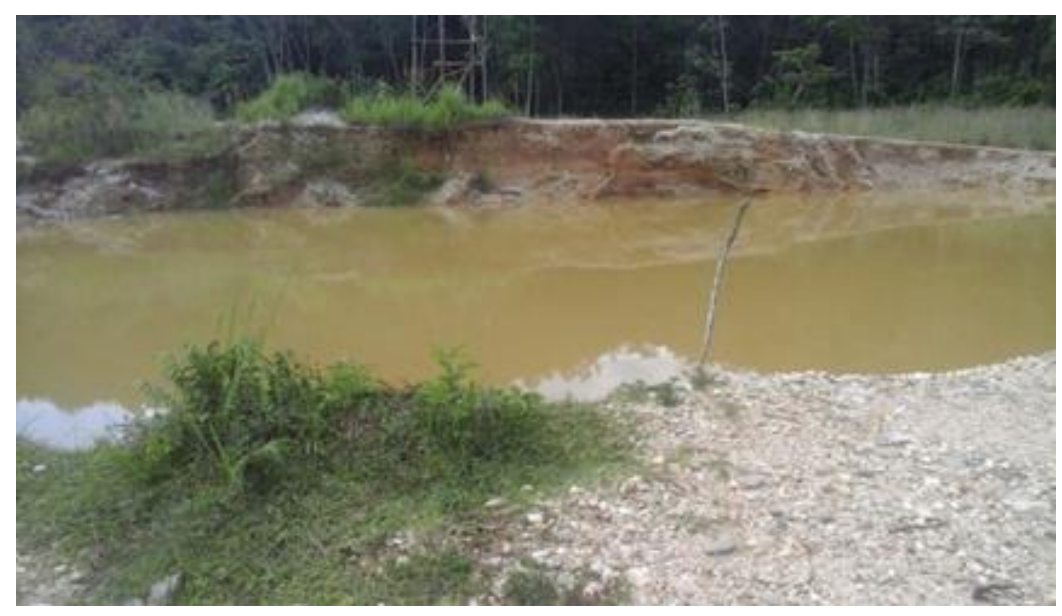

Gambar 8. Holes due to IGM activities that are not reclaimed

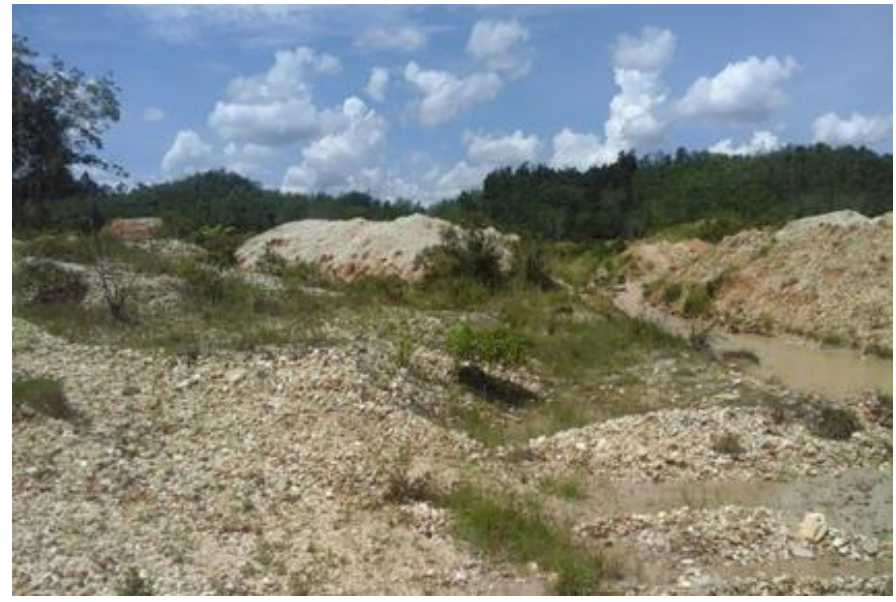

Gambar 9. Mounds of land due to abandoned IGM activities.

\subsubsection{Abrasion on the outskirts of the Batang Asai River and the land around the hole due to IGM activities}

The erosion of the soil surface (topsoil) due to IGM activities will continue to occur during the mining process taking place. Rock and soil destructions loss the functions of the soil and rock. The Batang Asai River has stated and widened, while the size of the holes is widening due 
to abrasion. This can be seen in Figure 5. The visualization presented in Figure 10 is a real condition of the abrasion process that occurs due to IGM activities. Soil abrasion occurs permanently and causes a decrease in soil fertility, river sedimentation and landslides. Sediment and abrasion avalanches on the excavated land will be transported into the river and cause siltation.

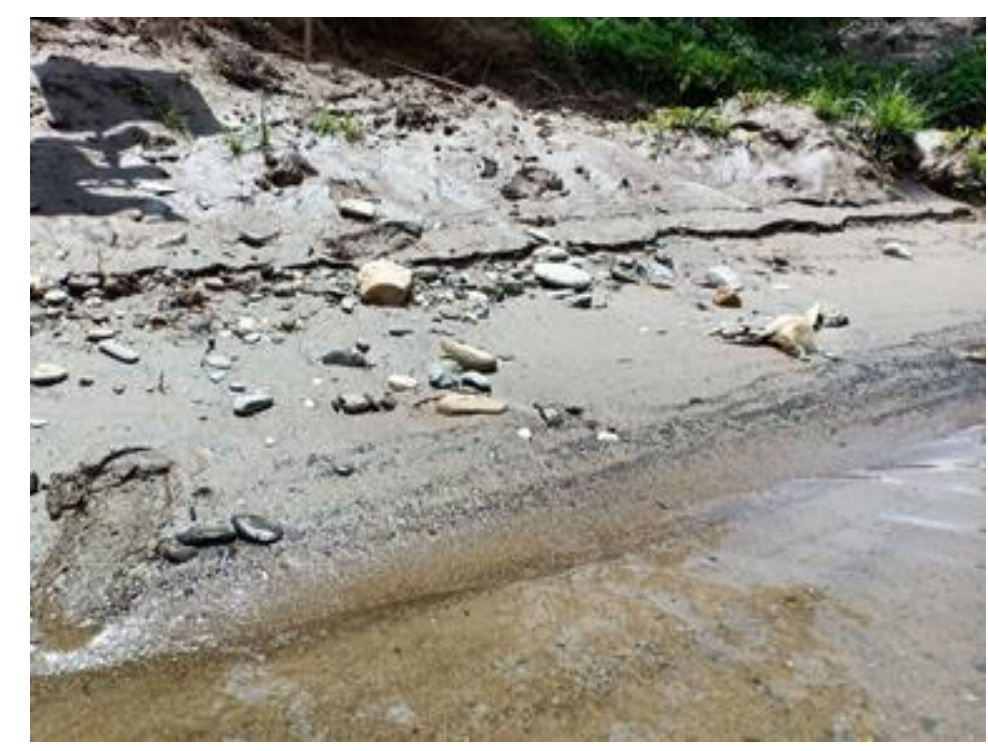

Gambar 9. Mounds of land due to abandoned IGM activities.

\subsection{Government efforts in overcoming the problem of IGM}

Based on the above explanation, we can understand that Batang Asai Village has been suffered by considerable damage due to IGM activities. Problems that have arisen are not only the responsibility of the government but also of all levels of society. The regional governments have carried out several programs and efforts in overcoming the problem of IGM activities. The first one was the counselling conducted by police. The police provided information about the impact of IGM activities that damage the environment, the landscape and society. This activity is usually carried out in the Sarolangun District Police by inviting Village Heads, Community Leaders and Customary Institutions.

Mr Arpan as the Head of Sub-District of Batang Asai District explained that the community continued to carry out IGM activities even though counselling had been carried out. The reason was that they felt that the land that was used as the location for IGM activities was private property and not owned by the government. This raises the pros and cons in the community. The government and the police have collaborated with village officials in the dissemination of the results of counselling to all residents. The government must be intensive and patient in conducting counselling. The effort to date has not been fully successful.

The second effort was giving sanctions (punishment) to mine workers in IGM activities. Giving sanctions is the last choice in an effort to overcome the negative impacts of IGM activities. With the provision of sanctions, it is expected that the public will realize that it is very important in maintaining a natural balance. Provision of sanctions carried out is non-judicial and legal 
actions in accordance with Regional Regulation No. 3 of 2012 concerning Management of Mineral and Coal Mining Businesses.

Non-judicial actions are carried out by giving a reprimand letter and making a statement so that the mining workers make business licenses within a predetermined period in accordance with the applicable SOP. If there is no permits and violation activities are continued to carry out then further action i.e. forceful efforts (investigation) and will be taken then the actors will be brought to the court. The solution to the impacts of IGM activities i.e. by carrying out reclamation and reforestation are the responsibility of all levels of society. The handling process cannot be done instantly but requires a precise program to be implemented. Similar research was also carried out in the Limun district of Sarolangun Regency (Yulianti et al., 2016). As the result, IGM activities received full attention so that they can be resolved properly. In addition, the Government must protect damaged areas caused by IGM activities for reclamation. This reclamation process must receive a budget from the government of Jambi Province (Ranjan, 2018)

\section{Conclusions}

The results of this study showed that the IGM activities carried out by miners in Pekan Gedang Village, Batang Asai District, Sarolangun District, Jambi have had various negative impacts on the environmental sector. This IGM activity has been carried out by the local community for a long time ago so that the damage it caused has been on a serious level. Environmental impacts that occur include noise pollution, dust, degradation of the Batang Asai River, conversion of forests into mining locations, siltation of rivers, emergence of large holes, overburdening, abrasion of riverbanks and holes, reduction on vegetation e.g. Meranti plants (Shorea sp.), Damar (Agathis Damara), and aquatic biota e.g. Semah Fish (Tor sp.). IGM activities provide income to sustain the economic life of the local community but an awareness of environmental preservation is needed. This is the responsibility of all levels of society. If this does not immediately get post-treatment, the damage will be worse. So far, the Regional Government of Batang Asai District has conducted counselling and sanctions (punishment) to regulate mining workers. However, this method has not been fully successful due to various obstacles, e.g. people feel entitled to private land without thinking about the impact on the environment. Reclamation and reforestation is not an easy and instant matter, yet it requires perseverance and patience in improving the quality of the environment so that it can be well inherited to the future generation. It seems it will be impossible to achieve if the regional government does not protect areas that have been legally damaged.

\section{Acknowledgement}

The author would like to thank Zainuri Anwar, ST, Irmawati Sagala, M.Sc., Deliza, M.Sc., Ika Nur Fitriani, M.Sc., the Sulthan Thaha Saifuddin Jambi Center for Educational Development (CED) forum, The DPD of the Indonesian Lecturer Forum (FDI) Jambi who have provided advice and insights through regular scientific discussions. Also, another gratitude is expressed to the reviewers who have provided suggestions for the perfection of this paper.

\section{References}

Andri DH, Anies, S. H. (2011). Kadar Merkuri pada Rambut Masyarakat di Sekitar Penambangan 
Emas Tanpa Izin. Pemberian Cairan Karbohidrat Elektrolit, Status Hidrasi Dan Kelelahan Pada Pekerja Wanita, 45(3), 181-187.

Angel, B. M., Simpson, S. L., Jarolimek, C. V., Jung, R., Waworuntu, J., \& Batterham, G. (2013). Trace metals associated with deep-sea tailings placement at the Batu Hijau copper-gold mine, Sumbawa, Indonesia. Marine Pollution Bulletin, 73(1), 306-313. http://doi.org/10.1016/j.marpolbul.2013.04.013

Auger, N., Duplaix, M., Bilodeau-Bertrand, M., Lo, E., \& Smargiassi, A. (2018). Environmental noise pollution and risk of preeclampsia. Environmental Pollution, 239, 599-606. http://doi.org/10.1016/j.envpol.2018.04.060

Avcl, D. (2015). Geoforum Mining conflicts and transformative politics : A comparison of Intag ( Ecuador ) and Mount Ida ( Turkey ) environmental struggles. Geoforum. http://doi.org/10.1016/j.geoforum.2015.07.013

Christine, L., Anderson, H., Karoui, H., Podgorski, J., \& Yacouba, H. (2018). Prediction model for cyanide soil pollution in artisanal gold mining area by using logistic regression. Catena, 162(November 2017), 40-50. http://doi.org/10.1016/j.catena.2017.11.018

Dutu, R. (2016). Challenges and policies in Indonesia â€тм s energy sector. Energy Policy, 98, 513-519. http://doi.org/10.1016/j.enpol.2016.09.009

Engstrom, D. R., Fitzgerald, W. F., Cooke, C. A., Lamborg, C. H., Drevnick, P. E., Swain, E. B., ... Balcom, P. H. (2014). Atmospheric Hg Emissions from Preindustrial Gold and Silver Extraction in the Americas: A Reevaluation from Lake-Sediment Archives.

Ferring, D., Hausermann, H., \& Effah, E. (2016). The Extractive Industries and Society Site speci fi c : Heterogeneity of small-scale gold mining in Ghana. The Extractive Industries and Society, 3(1), 171-184. http://doi.org/10.1016/j.exis.2015.11.014

Hazelhoff, M. H., \& Torres, A. M. (2018). Gender differences in mercury-induced hepatotoxicity: Potential mechanisms. Chemosphere, 330-338. http://doi.org/10.1016/j.chemosphere.2018.03.106

Hoeber, O., Hoeber, L., Snelgrove, R., \& Wood, L. (2017). Interactively producing purposive samples for qualitative research using exploratory search. CEUR Workshop Proceedings, $1798,19-21$.

Kepala Desa. (2017). Laporan Tahunan Desa Pekan Gedang.

Kitula, A. G. N. (2006). The Environmental and Socio-economic Impacts of Mining on Local Livelihoods in Tanzania: A Case Study of Geita District. Journal of Cleaner Production, 14(14), 405-414. http://doi.org/10.1016/j.jclepro.2004.01.012

Kumar, A., Divoll, T. J., Ganguli, P. M., Trama, F. A., \& Lamborg, C. H. (2018). Presence of artisanal gold mining predicts mercury bioaccumulation in five genera of bats (Chiroptera ) *. Environmental Pollution, 236, 862-870. http://doi.org/10.1016/j.envpol.2018.01.109

Langston, J. D., Lubis, M. I., Sayer, J. A., Margules, C., Boedhihartono, A. K., \& Dirks, P. H. G. M. (2015). Comparative development benefits from small and large-scale mines in North Sulawesi, Indonesia. Extractive Industries and Society, 2(3), 434-444. http://doi.org/10.1016/j.exis.2015.02.007 
Limbong, D., Kumampung, J., Rimper, J., Arai, T., \& Miyazaki, N. (2003). Emissions and environmental implications of mercury from artisanal gold mining in North Sulawesi, Indonesia. The science of the Total Environment, 302(1-3), 227-236. http://doi.org/10.1016/S0048-9697(02)00397-2

Male, Y. T., Reichelt-Brushett, A. J., Pocock, M., \& Nanlohy, A. (2013). Recent mercury contamination from artisanal gold mining on Buru Island, Indonesia - Potential future risks to environmental health and food safety. Marine Pollution Bulletin, 77(1-2), 428-433. http://doi.org/10.1016/j.marpolbul.2013.09.011

Nakazawa, K., Nagafuchi, O., Kawakami, T., Inoue, T., Yokota, K., Serikawa, Y., ... Elvince, R. (2016). Human health risk assessment of mercury vapour around artisanal small-scale gold mining area, Palu city, Central Sulawesi, Indonesia. Ecotoxicology and Environmental Safety, 124, 155-162. http://doi.org/10.1016/j.ecoenv.2015.09.042

Owusu-Nimo, F., Mantey, J., Nyarko, K. B., Appiah-Effah, E., \& Aubynn, A. (2018). Spatial Distribution Patterns of Illegal Artisanal Small-Scale Gold Mining (Galamsey) Operations in Ghana: A focus on the Western Region. Heliyon, 4(2), 1-36. http://doi.org/10.1016/j.heliyon.2018.e00534

Palacios-torres, Y., Caballero-gallardo, K., \& Olivero-verbel, J. (2017). Mercury pollution by gold mining in a global biodiversity hotspot, the Choco biogeographic region, Colombia. Chemosphere. http://doi.org/10.1016/j.chemosphere.2017.10.160

Ramires, C. R. (2007). Ethnobotany And The Loss Of Traditional Knowledge In The 21st Century. Ethnobotany Research \& Applications, 5, 245-247.

Ranjan, R. (2018). The role of political-industry nexus in promoting illegal extraction of mineral resources and deforestation: A case of iron ore mining in Goa. Resources Policy, (February), 1-15. http://doi.org/10.1016/j.resourpol.2018.02.010

Rava, T., \& Ramirez, D. (2018). A Systematic Review on The Management and Treatment of Mercury in Artisanal Gold Mining. The science of the Total Environment, 633, 816-824. http://doi.org/10.1016/j.scitotenv.2018.03.241

Rettberg, A., \& Ortiz-Riomalo, J. F. (2016). Golden Opportunity, or a New Twist on the ResourceConflict Relationship: Links Between the Drug Trade and Illegal Gold Mining in Colombia. World Development, 84, 82-96. http://doi.org/10.1016/j.worlddev.2016.03.020

Shepherd, T., Rumengan, I., \& Sahami, A. (2018). Post-depositional behaviour of mercury and arsenic in submarine mine tailings deposited in Buyat Bay, North Sulawesi, Indonesia. Marine Environmental Research. http://doi.org/10.1016/j.marenvres.2018.02.028

Simbolon, D., Maxwel, S., Yulina, S., \& Metode, M. (2010). Kandungan Merkuri dan Sianida pada Ikan yang Tertangkap dari Teluk Kao, Halmahera Utara. Ilmu Kelautan, 15(3), 126-134.

Spiegel, S. J. (2012). Governance Institutions, Resource Rights Regimes, and the Informal Mining Sector: Regulatory Complexities in Indonesia. World Development, 40(1), 189-205. http://doi.org/10.1016/j.worlddev.2011.05.015

Steckling, N., Tobollik, M., Plass, D., Hornberg, C., Ericson, B., Fuller, R., \& Bose-O’Reilly, S. (2017). Global Burden of Disease of Mercury Used in Artisanal Small-Scale Gold Mining. Annals of Global Health, 83(2), 234-247. http://doi.org/10.1016/j.aogh.2016.12.005 
Supangat A.B. (2013). Pengaruh gangguan pada kawasan hutan lindung terhadap kualitas air sungai: studi kasus di provinsi jambi. Indonesian Forest Rehabilitation Journal, 1(1), 75-89.

Syarifah Nurdawati, Niam Mulikhah, M. D. S. (2006). Sumber Daya Perikanan Perairan Sungai Batanghari Jambi. Bawal, 1(1), 1-9.

Telmer, K. H., \& Veiga, M. M. (2008). World emissions of mercury from artisanal and small-scale gold mining. Mercury fate and transport in the global atmosphere: measurements, models and policy implications (UNEP global mercury partnership, mercury transport and fate research partnership ar. In Springer (pp. 131-132). http://doi.org/10.1007/978-0-38793958-2

Tudesque, L., Grenouillet, G., Gevrey, M., Khazraie, K., \& Brosse, S. (2012). Influence of small-scale gold mining on French Guiana streams: Are diatom assemblages valid disturbance sensors ? Ecological Indicators, 14, 100-106. http://doi.org/10.1016/j.ecolind.2011.07.018

Veiga, M. M., Angeloci-Santos, G., \& Meech, J. A. (2014). Review of barriers to reduce mercury use in artisanal gold mining. Extractive Industries and Society, 1(2), 351-361. http://doi.org/10.1016/j.exis.2014.03.004

Veiga, M. M., Angeloci, G., Hitch, M., \& Colon Velasquez-Lopez, P. (2014). Processing centres in artisanal gold mining. Journal of Cleaner Production, 64, 535-544. http://doi.org/10.1016/j.jclepro.2013.08.015

Werthmann, K. (2017). The drawbacks of privatization: Artisanal gold mining in Burkina Faso 1986-2016. Resources Policy, 52(January), 418-426. http://doi.org/10.1016/j.resourpol.2017.04.007

Yulianti, R., Sukiyah, E., \& Sulaksana, N. (2016). Dampak Limbah Penambangan Emas Tanpa Izin (PETI) terhadap Kualitas Air Sungai Limun Kabupaten Sarolangun Propinsi Jambi. Bulletin of Scientific Contribution, 14(3), 251-262.

Zolnikov, T. R. (2012). Science of the Total Environment Limitations in small artisanal gold mining addressed by educational components paired with alternative mining methods. Science of the Total Environment, The, 419, 1-6. http://doi.org/10.1016/j.scitotenv.2012.01.017

Zvarivadza, T., \& Nhleko, A. S. (2017). Resolving artisanal and small-scale mining challenges: Moving from conflict to cooperation for sustainability in mine planning. Resources Policy, (August), 0-1. http://doi.org/10.1016/j.resourpol.2017.12.003 